\title{
PSYCHOLOGICAL IMPLICATIONS OF OUTDOOR ADVENTURE MODEL OF EDUCATION
}

\author{
PAULINA KIDA \\ Department of Pedagogy, University of Wrocław \\ Dawida 1, 50-527 Wrocław \\ E-mail address: paulinakida@gmail.com
}

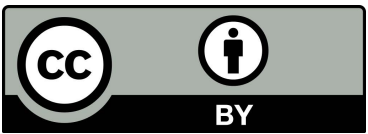

\section{ABSTRACT}

The article is a synthetic analysis of the Outdoor Adventure Education model in the context of three elementary components: the environment - in relation to the theory of space from the perspective of sociological and pedagogical theory of space; personal perspective and growth as well as social development - in relation to psychological phenomena that accompany the individual and group involved in the process of Outdoor Adventure Education. The aim is to present how these processes determine the effects of education and what personalities' elements are involved.

Key words: self-development, outdoor education, adventure education, comfort zone, space and place.

Nature never gets boring. (Konner, 1972, p. 9)

\section{INTRODUCTION}

The area of theoretical considerations about psychological aspects of learning, theory of teaching and in the field of psycho-development has a universal set of issues of interest. The foundations of psychological and pedagogical theories are derived from the works of the founding fathers of these scientific fields, among which we can list: Jean Piaget, Erik Erikson, Lawrence Kohlberg or David Allen Kolb. Education understood as a process - not only of teaching but also of shaping a man - stands at the crossroads of many auxiliary sciences but it draws the most from psychology. The review of literature on the subject of Outdoor Adventure Education was based mainly on the British and American sources. The proper literature was found mainly in databases on education (BIDS), physical education (SPORTDISCUS) and psychology (PSYCHLIT) (Rubens, 1997).

The article is an attempt to both popularise and synthesise the psychological processes activated in the process of Outdoor Adventure Education. Method of education through experience and adventure, while in the bosom of nature, has a long history. It draws from many well-known methods with long and widely recognised traditions, such as scouting and path-finding. The 
father of this movement in the UK was Robert Baden-Powell; in the USA Ernest Thompson Seton; in Poland - Andrzej Małkowski. All of the mentioned people were operating at the turn of the 20th century. Valuable literature of the subject also comes from this period and includes such works as: Scouting jako system wychowania młodzieży [Scouting as a System of Youth Upbringing] by A. Małkowski (1911), Scouting for Boys by R. Baden-Powell (1908) or The Book of Woodcraft and Indian Lore by E.T. Seton (1913).

Outdoor Adventure Education has a large amount of practitioners (such as: Mark Leather, Hamish Wilson and Su Porter form the University St Mark \& St John in Plymouth, Magdalena Jędrzejczyk from The School of Active Recreation "Frajda" or Shawn Moriarty and Joey Jarrell from The Outdoor and Adventure Education Programs Professional Group) and theorists (such as: John Dewey, Alan Ewert, Maurice Gibbons, David Hopkins, James Neill, Dick Prouty). It is also the subject of studies in North America (e.g. Bobilya, Akey, \& Mitchell, 2011; Cason, \& Gillis, 1994), Australia (e.g. Martin, 2008; Gray, \& Martin, 2012) and in Europe (e.g. Gustafsson, Szczepanski, \& Nelson, 2012; Scrutton, 2014). Professional scientific journals - such as: Journal of Adventure Education and Outdoor Learning, Applied Environmental Education and Communication, Australian Journal of Outdoor Education, Journal of Experiential Education - are dedicated to it. It is a method of work which involves emotions, is conducive to self-development and developing motivation (Rickinson et al., 2004). It uses nature as a tool for achieving educational goals. This article presents an excerpt of an overall teaching method, focusing mainly on elements of psychology contained in it.

\section{DEFINITIONS}

The complex nature of Outdoor Adventure Education calls for analysis. Specific definition has to be chosen - it is especially important in the initial phase of considerations. Research concepts, which are taking into account the various theorists and periods in the history of Outdoor Adventure Education, show the evolution of the concept from the J. Dewey's Experiential Education, through autonomous experience of British and American Outdoor Education, Adventure Education, to the contemporary recognition method called Outdoor Adventure Education.

The National Association of Outdoor Education (NAOE) defines the Outdoor Education after John Hunt: "Outdoor Education is a means of approaching educational objectives through guided direct experience in the outdoor environment, using its resources as learning materials. This experience combines both a study of environmental aspects and topics and participation in those activities associated with the natural environment" (Hunt, 1989, p. 53). Peter Higgins and Chris Loynes, researchers from the United Kingdom, point out the ambiguity of this definition and suggest a set of characteristics created for the European Institute for Outdoor Adventure Education: “The educational 
intention is to stimulate personal and social development. The themes of Outdoor Adventure and Education are all important to some degree in the process which should not simply be recreational, nor should it take place without at least some experience of the outdoors. Adventure in this context implies that there is a 'journeying out' (a move onto new ground) to embrace the experience. [...] To maximise the effect, the experience should be direct rather than mediated. [...] Outdoor Education programmes should also encourage participants to develop respect for the environment. This respect is extended and developed through the concept of »friluftsliv« which seeks, through an experiential approach to a simple way of living, to help people rediscover the natural world as the true home of our cultures. As a result of this experiential process, participants should take increased responsibility for their own learning, and consequently develop increased confidence in their own judgement and ability to direct their lives" (Higgins, \& Loynes. 1996, pp. 2-3).

The Association of Experiential Education defines Experiential Education as "a process through which a learner constructs knowledge, skill, and value from direct experience" (Luckmann, 1996, p. 7) and adds that "in practice »natural landscapes « are regarded as typical foci for Experiential Learning" (Luckmann, 1996, p. 6). Scott Wurdinger identifies three main themes underpinning Adventure Education. These are: "using experience to enhance the educational process, building moral character, and developing a willingness to take risks" (Wurdinger, 1995, p. 1). John C. Miles and Simon Priest think that "adventure education involves the purposeful planning and implementation of educational processes that involve risk in some way" (Miles, \& Priest, 1990, p. 1).

The Outdoor Adventure Education methods glorify the direct experience, lined with strong, emotional experiences, where students expand their comfort zones, strengthen the willingness to undertake new challenges and open themselves to innovative ideas. Analysis of definitions from which the modern concept of Outdoor Adventure Education evolved allowed to identify three essential elements of this method: specific place - in nature, specific activities involving physiognomy and psychology of people, and processes of self-development and self-motivation.

\section{POWER OF SPACE}

Both the psychologists and educators agree that space in which the individual and the group function determines reactions and attitudes - open or closed to experiences available in this space. The role of space and place is getting more attention among scientists; but such classic thinkers as Plato, Yi-Fu Tuan and Martin Heidegger should also be included among its researchers. One of the most important aspects of space, often omitted in the analysis, is its psychological and social perception.

The philosophical considerations of place and space made by Friedrich Nietzsche and M. Heidegger are converging in terms of content, time and place. F. 
Nietzsche has described from an ontological perspective the fact that identity, which belongs to "the order of being", is located in the material word, in the physically perceived place; namely, the being lives in the body and is the body. It creates the concept of being - with the emphasis on being through which existence takes place (Nietzsche, 1911). F. Nietzsche clearly goes against metaphysics. He inextricably links the material being with being, as if no spirit can exist outside the body. In this perspective, a place of being of a man means a place in which his material form (body) is located. M. Heidegger, on the other hand, writes about a phenomenon of Dasein, which (from German) means "being in the world" (Heidegger, 1962). For this representative of the German philosophical thought of the turn of the 20th century, being of a man encompasses more than just being in the world - it is "being here" which indicates being with the world and not only in it. This is a valuable perspective thanks to which the inseparable man and place interact with one another. This is a relentless, two-way relation. Both F. Nietzsche and M. Heidegger, however, reject the possibility of a metaphysical perception of a place, thus trapping the soul in the body.

The work of Y.-F. Tuan Space and Place: The Perspective of Experience from 1977 is a milestone on the path of scientific knowledge. He is a specialist in the field of science called humanistic geography. In the 60s, it served as counterweight to the quantitative trend in geography - oriented towards electronic counting, measuring and computer data processing (Wojciechowski, 1987). The American scientist has created the concept of place and space in the individualistic viewpoint. This humanistic perspective provided measurable things within the social dimension. Y.-F. Tuan noted that people find place and space obvious and do not reflect upon them. He himself started wondering about them. He stated that "place is security, space is freedom: we are attached to the one and long for the other" (Tuan, 1977, p. 3). This definition shows an emotional dimension attributed to categories of place and space. Place is strongly marked with personal feelings. Y.-F. Tuan writes that: "relatively few works attempt to understand how people feel about space and place, to take into account the different modes of experience (sensorimotor, tactile, visual, conceptual), and to interpret space and place as images of complex - often ambivalent - feelings" (Tuan, 1977, pp. 6-7). So, place is a part of our biography, it is an important element not just a background. The author does not describe the place only in the emotional category. He shows that it is strongly related to paths on which thoughts and experiences run: "To experience is to learn; it means acting on the given and creating out of the given. The given cannot be known in itself. What can be known is a reality that is a construct of experience, a creation of feeling and thought" (Tuan, 1977, p. 9). Place is not only a scrap of space marked with emotions, it is an element which has been cognitively tamed. The author also emphasises the role of values which along with emotions and intellectual knowledge - make space into place: "Space is more abstract than "place«. What begins as undifferentiated space becomes place as we get to know it better and endow it with value" (Tuan, 1977, p. 6). Y.-F. Tuan puts these considerations in the dynamic perspective: "The ideas »space« and »place« require each other for definition. From the security and stability of 
place we are aware of the openness, freedom, and threat of space, and vice versa. Furthermore, if we think of space as that which allows movement, then place is pause; each pause in movement makes it possible for location to be transformed into place" (Tuan, 1977, p. 6). The scope of the experience of place is intimate and direct, of space - indirect and conceptual; they exist in symbiosis.

In the context of considerations on place and space, the work of Edward Twitchell Hall shows the cultural dimension of space. The titular, hidden dimension should be understood as experiencing of space by man. In this experience, a large role is played by the "distance receptors - those concerned with examination of distant objects - the eyes, the ears, and the nose. [...] The immediate receptors - those used to examine the world close up - the world of touch, the sensations we receive from the skin, membranes, and muscles" (Hall, 1990, p. 41). In an attempt to create spatial typology of proxemics, we can distinguish its three types:

- Fixed-feature space - understood as one of the primary ways of organising both individual and group activities; manifested, among others, in buildings, the way of grouping them and their internal division. This, in turn, is culturally determined: the adopted patterns of city layout will be conditioned by culture and will reflect trends of the era.

- Semifixed-feature space - space in which mobile objects are located; they can be moved, removed, etc. These changes are non-invasive, space remains intact. The examples of these include furniture or design elements which do not interfere with the overall layout of the room. It can have a sociopetal nature - when the space enables the closeness, conversation, establishment of relationships - or a sociofugal onewhen it stands in the way of these types of interactions.

- Informal - when space is perceived in psychological terms, through the prism of personal distances: intimate, individual, social and public (Hall, 1990).

The first of them is responsible for internalisation of practices imposed by the specific spatial arrangement. The fixed-feature space is a form of template to which the behaviour of man has to conform. When he or she recognises the type of space - whether this is a school, a hospital, a park - he or she initiates proper behaviour and performs culturally determined actions. Some examples could be: putting the jacket in the locker room, purchasing protective footwear, eating breakfast without shoes while sitting on a blanket. These actions are undertaken without prior verbalisation or acquiring consent of the environment. Space teaches patterns which are replicated many times, thus, becoming the internalised rules of conduct within it. This does not only happen in institutions, situation is similar in the case of a house. Rooms inside it, even on the semantic of the building itself, reveal their functions and, hence, determine what activities are undertaken by people in them. And so, the bedroom or the living room impose certain conventional behaviour (Hall, 1990).

An example used by E.T. Hall to describe the semifixed-feature space is one Canadian experiment which showed behaviour determined by this type 
of space. A doctor named Humphry Osmond has noticed that certain spaces, like railway waiting rooms, cause people to keep distance from one another. They are of sociofugal nature. One the other hand, objects such as tables in cafés gather people closer together, creating a sociopetal space. In the hospital, $\mathrm{H}$. Osmond observed that the personnel preferred sociofugal spaces because it was easier to keep order there. On the newly built geriatrics ward, despite its aesthetic interior, the patients did not start any conversations due to arrangement of furniture. E.T. Hall writes: "the longer the patients stayed in the ward, the less they seemed to talk to each other. Gradually, they were becoming like the furniture, permanently and silently glued to the walls at regular intervals between the beds. In addition, they all seemed depressed" (Hall, 1990, p. 108).

The problem of space and place in Polish education has been tackled by Maria Mendel. The definition of place created by her describes it as micro space, a separate part of space, "a well-know piece of reality with provocative, enticingly open character" (Mendel, 2006, p. 21). She has created the concept of pedagogy of space, defining it as "the potentially supporting category which can stimulate and support the interpretation and creation processes focused on places as well as patterns of pedagogical thinking" (Mendel, 2006, p. 22). Definition of space most prominent in Polish sociology was created by Florian Znaniecki. Referring to the creators of the Chicago Ecological School that deal mainly with urban space, he distinguished space in the physical, geometrical and social sense: "social space of certain community is an area that it uses and shapes; an area associated with certain knowledge system, ideas, values and rules of conduct - as a result, it is an area that the community most identifies with" (Znaniecki, 1938, p. 90). He further adds that "the experience is connected to numerous spaces which are diverse in quality, limited, indivisible, variable and, at the same time, rated as positive or negative" (Znaniecki, 1938, p. 91). The essence of meaning of space is found in these words, in the aspect most significant from the pedagogical point of view and in accordance with the concept of pedagogy of space created by M. Mendel.

The primary feature of Outdoor Adventure Education is planning educational situations in nature. As justifiedly observed by Fiona Danks and Jo Schofield: "Unfortunately, many children grow up alienated from wild places, wary of the countryside because it lacks the hard edges of civilization. In our headlong rush to embrace change and progress, our lives grow further and further away from natural rhythms, and some people seem anxious to keep all wild things at bay. The lives of ancient peoples were completely intertwined with natural cycles; they recognised they were an integral part of the world and knew how to use it without abusing it" (Danks, \& Schofield, 2007, p. 13). Similar conclusion about the lack of places in urban space for children to play while in contact with nature seems to be shown on a piece of street art by Banksy entitled Swing Girl (see: Fig. 1). Yet, we could argue that the author here is not only pointing out a problem but also advocating a proper direction of change in the city space. 
Fig. 1.

Swing Girl by Banksy Streetart by Banksy showing the direction of changes in urban society (source: Webster, 2015).

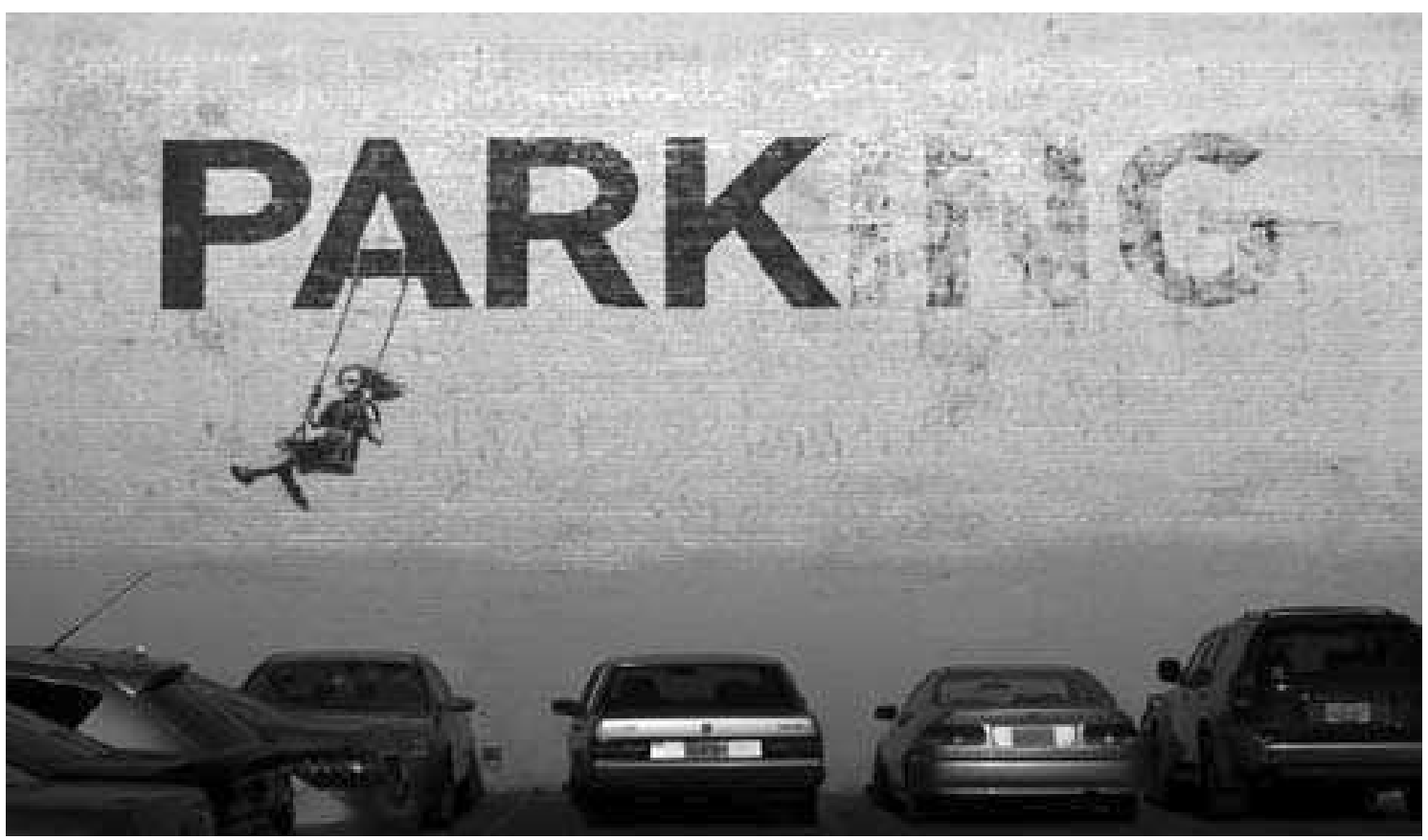

In more philosophical terms, we can note a gap in disciplines that seek to fulfil objectives of sustainable development. It is located in education: "In order to consciously shape human needs in a way that enables the positive relation of man to nature, development of human sciences is urgently needed. Development of psychology, philosophy, ethics, politics and, above all, the theory of education. Education sciences and political sciences, next to eco-philosophy, provide the possibility of open shaping of human nature as a new subject of historical development. And, contrary to the suggestions of some visionaries such as Francis Fukuyama, this cannot be done through genetic engineering" (Piątek, 2005, p. 21).

Elżbieta Szczepaniec-Cięciak's comment can be construed as a proposal to remedy this situation: "Polish education is dominated by the »feeding" teaching methods. We should develop and promote interactive methods which are particularly useful in the sphere of ecological education. This requires a greater interest in methodology of ecological education in pedagogical context as well as the psychological, sociological and natural ones" (Szczepaniec-Cięciak, 2004, p. 257). The sought-after tool, which could change the present state of affairs, is the methodology of education in the environment and constructivist teaching model. Environmental education should be implemented as education "about" the environment, "for" the environment and "in" the environment (Christ, 2012). The first aspect means conveying a set of information "about" something, for example: about which trash is recyclable. Education "for" means teaching to actively operate for the sake of environment. The last aspect - "in", also understood as "through" the envi- 
ronment, is manifested in the multi-sensational cognition, research process and field work. Education "for" and "through" are aspects which should be most emphasised. This model of education contributes to the internalisation of attitudes and values. Children currently have very few opportunities to stay in the natural environment. Yet, in order to establish a direct link, it is necessary for a child to be close to nature - to regularly spend time in the forests, fields, meadows or gardens as well as to experience those places with all senses, in the most individualised and personal way (Leksicka, 1999). The process of education "about" the environment implemented "in" and "for" the environment is best illustrated by the diagram of ecological steps created by Lidia Wollman-Mazurkiewicz (see: Fig. 2).

\section{Fig. 2.}

Ecological steps: Wollman-Mazurkiewicz, L. (2000). Na tropach praktyki w klasach młodszych [Hunting for practice in primary education]. In: B. Dymara (Ed.) Dziecko w świecie przyrody [Child in the world of nature] (p. 213). Kraków: IMPULS, own diagram.

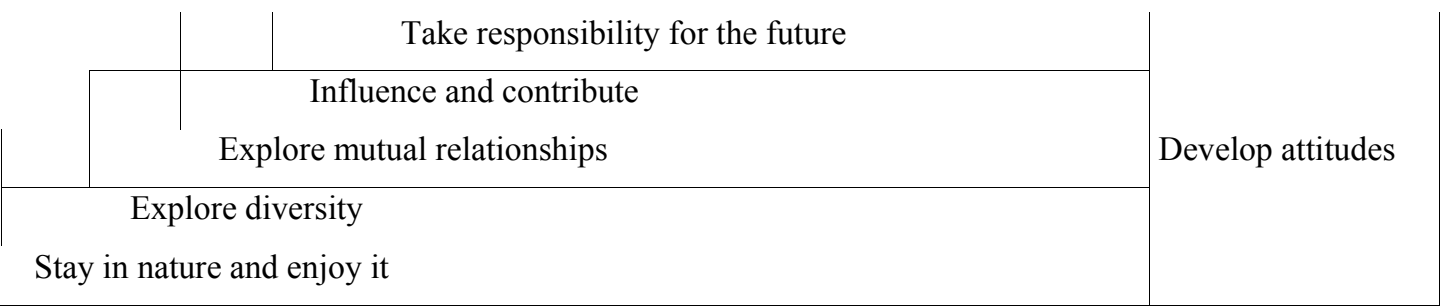

The first three steps presented in Fig. 2 are meant for preschool children, while the next ones should be implemented at higher levels of education. The first step takes into account direct contact with nature, multi-sensory experiences, creation of circumstances for shaping an emotional connection to nature - those are all types of activities which cannot be taught to children remaining at the "about" level education. The next two steps help with discovery of different environmental elements and their dependencies (Wollman-Mazurkiewicz, 1998).

The role of space in the Outdoor Adventure Education process determines the success or failure of working with this method. In accordance with afore-mentioned definitions presented by F. Nietzsche, E.T. Hall, M. Heidegger and M. Mendel, space provides, in a way, psychological grounds of relationships - it enables or inhibits self-development, stimulates or suppresses motivations and supports or curbs the dynamics of a group. 


\section{POWER OF ACTIVITY}

Scope of specific features and guidelines of Outdoor Adventure Education make it different from cultural tourism, Outdoor Education, environmental education and physical education. A particular mixture of methods, objectives, as well as psychologically activated processes make up its specific and autonomous character. At the same time, they make it one of the most valuable tools of holistic education. The success of the educational process depends mainly on whether targets such as internalisation of attitudes and direct emotional experiences were included in the stage of planning. Properly planned process is conducive to activation of specific psychological processes.

Activities that are involved in the educational process in the described model have a unique character because of the psychological processes involved. Key features of physical "adventure" activities are that they:

- Provide a level of physical challenge or difficulty greater than in everyday life of an average participant and, hence, extend participants' behaviour beyond normal everyday patterns;

- Include, in the participants' perception, a sense of taking physical risk although this "risk element" is not always useful (Ringer, 2004);

- Often create situations where participants are motivated to cooperate in order to succeed in the adventure;

- Sometimes involve an element of problem solving;

- Provide opportunities for participants to experiment, innovate and construct for themselves parallels between success in the adventure activity and expectations of success in everyday life (Hovelynck, 2000). Some practitioners will offer a "metaphor" linking the adventure with everyday life (Gass, 1995);

- Create physiological and biochemical changes in participants which tend towards greater health (Ringer, 2004).

The above description indicates a contrast between described activities and everyday life of participants who, therefore, find themselves outside their comfort zone. Activities here are focused not on target but on the process of solving problems and on the process of transgression which takes place in the biological and psychological context.

The actions and activities within Outdoor Adventure Education have some dependencies, presented in the general theory of education. The cycle created by D.A. Kolb (1984) - which combines the achievements of J. Dewey (1910), Aleksander Lewin (1983) and J. Piaget (1937) - is also a diagram introducing processes of education for understanding which take place within the described method. D.A. Kolb recognised education as a process, in which knowledge is created through transformations and experience. However, a simple experience is not sufficient for teaching - it requires complementary elements. D.A. Kolb described this process in the form of a cycle presented in the diagram below (see: Fig. 3). 
Fig. 3.

Kolb's cycle - The Lewinian Experimental Learning Model

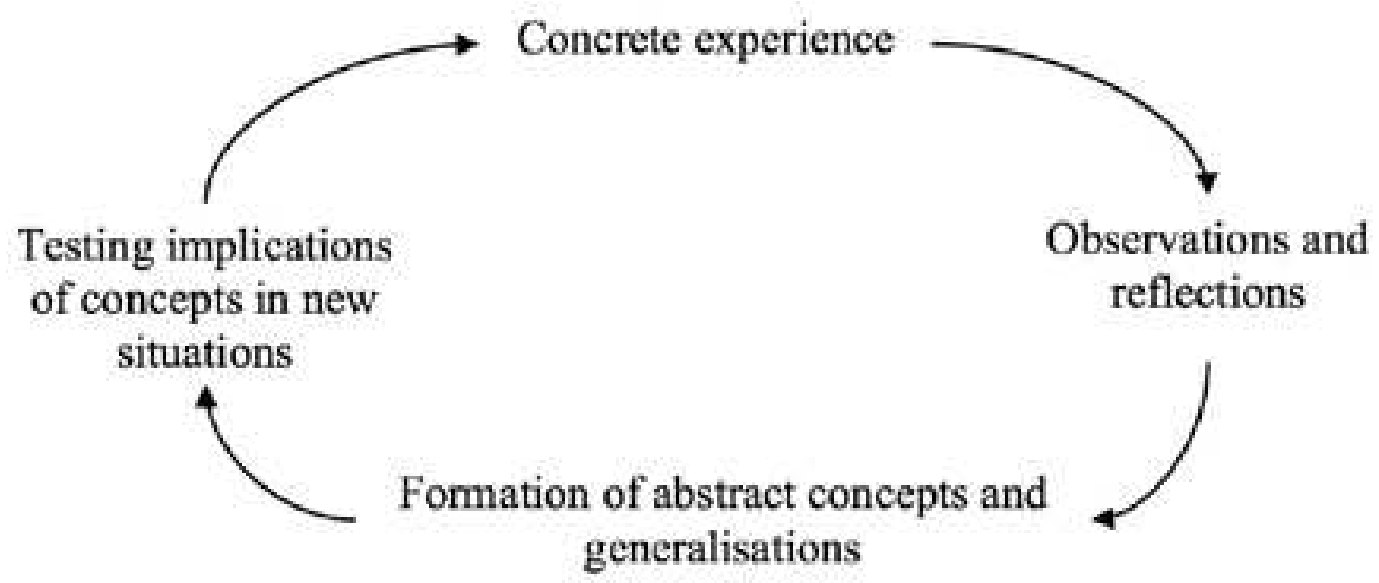

Source: Kolb, 1984, p. 21

Kolb's cycle, in the practical perspective, can be explained with one slogan: "plan, do, verify". As a result, knowledge gains a personal character, direct experience provides it with an emotional element. Education often emphasises the role of primary and secondary socialisation, while not much attention is paid to the socialisation coming from spaces. The process described by the presented diagram (see: Fig. 3) takes place constantly in each area where the educational opportunity appears, often spontaneously. Mainly, it shows that teaching does not only take place in planned conditions. Methods of Outdoor Adventure Education can be applied in the form of observing nature, field classes organised by the State Forests or Landscape Parks, races, classes with elements of survival, school trips and even forest nurseries which are gaining popularity in Poland. Applying those methods allows for internalisation of values necessary to implement rules of sustainable development in various aspects of human functioning.

Constructivism should become the basic assumption while creating educational methods based on experience. Its principles are based on belief that learning depends on knowledge acquired from personal experiences. In the process of construction, the man creates his own, personal, unique knowledge. Due to the fact that everyone is subject to diverse impacts, processing of information is ongoing. Teaching in the spirit of the constructivist theory of education causes reorganisation of existing knowledge, without limiting learning to the situation in which each new information is simply added to the information pool we already posses. Constructivism reinforces behaviour born from curiosity and that, in turn, results in the intense formation of meanings, equips children with a set of behaviours, which will be used in problematic situations. Stages of the educational process in the described theory are characterised by strictly defined order: recognising knowledge, disclosing preliminary ideas, restructuring knowledge, applying new knowledge, referencing altered ideas to the previous ones (Śniadek, 2007). 
Another key concept in the field of psychology is a question of motivation. Motivation causing commitment to the action for itself, without external rewards, is an intrinsic motivation. These are activities that people perform because they like it. Individuals are motivated internally and deeply interested in performed activity. External (extrinsic) motivation, on the other hand, forces an individual to commit to an action for the sake of its external results. Behaviour motivated extrinsically is a tool for obtaining benefits, while intrinsically motivated behaviour has no other goal than the direct rewards coming from it. Going to work we do not like is motivated externally, hiking in the mountains for pleasure - internally. Studies on children performed by Mark Lepper in 1973 showed that when additional prizes are involved the fun becomes work, motivation has external character and joy from the performed actions is reduced (Lepper, Sethi, Dialdin, \& Drake, 1997). Assessment and control impact the motivation. In addition, it is believed that actions, which are motivated internally, are associated with a special state of mind, called the flow. Its experience is characterised by the pleasant loss of self-awareness and sense of time, coupled with the deep focus on the task itself and not on its result. Flow is an integral part of creative process, it is an effect of extreme motivational commitment to activity and not its potential consequences. It is a reward for intrinsic motivation (Gerrig, \& Zimbardo, 2002). Intrinsic motivation is a key tool but it is also a step on the road to Outdoor Adventure Education. Some seek it by taking stimulants - usually in the context of work, rather than rest or fun.

Certain general ideas of psychology of emotion, motivations to move outside of the comfort zone and some areas of developmental psychology are also important factors to consider when planning Outdoor Adventure Education. Pete Allison, Malcolm Thornburn, John Telford and Aaron Marshall are the authors of control questions which are a valuable tool for evaluating any Outdoor Adventure program in terms of its value from the perspective of learning and teaching.

"Learning:

- Were learners aware of the aims of activities and scheduled learning experiences?

- Was there a regular ongoing overview of learning aims?

- Were the learners actively involved in constructive dialogue with other learners?

- Did learners assume some »active" responsibilities for their own learning?

- Could learners begin to see problems from different perspectives?

- Could learners merge reason and feelings?

- Did facilitating learning lead to some learners appearing unduly lost?

- Could learners be trusted to remain on task?

Teaching:

- Were you aware of the values you brought to the learning setting?

- Were you aware of the implicit values conveyed by the learning setting? 
- Were you confident in your ability to set up learning tasks?

- Could you adapt to teaching in more uncertain teaching and learning environments

- Were you able to limit the amount of time you talked to the whole group?:

- Could you cater for most individual learner differences?

- What types of questions did you ask: e.g. convergent, divergent? Were these appropriate?

- Were you able to trust learners and »wait« for real learning gains to occur?" (Allison, Thorburn, Telford, \& Marshall, 2011, p. 213).

In Outdoor Adventure Education, just like in every planned educational situation, each group process requires evaluation. The check-list presented above shows some critical elements of values-based Outdoor Adventure Education. These questions - in relation to objectives, processes, responsibilities and the nature of personal relationships - can help assess whether the planned process meets the requirements of Outdoor Adventure Education; or maybe it treats the subject rather superficially or realises some other educational agenda.

\section{CONCLUSION}

Involvement of issues such as motivation, learning through experience, subjecting experiences to reflection, concepts of self-development, motivation and expanding interpersonal competencies during group processes indicates the exceptional character of Outdoor Adventure Education in psychological and educational contexts. This method allows us to educate people as well as to shape their personalities. It constitutes the example of teaching how to not only find a solution to a problem, but also successfully carry out the process of solving it while using the resources of own personality and knowledge. It activates the motivation to plan and implement plans for self-development. Direct and personal nature of experiences involved in this model of education allows to shape a person who is self-conscious, reflective, responsible for his/her community and the environment. This makes Outdoor Adventure Education one of the few models of education which can be successfully implemented in the system of education.

\section{REFERENCES}

[1] Allison, P., Thorburn, M., Telford, J., \& Marshall, A. (2011). Values in adventure education: Happy and wise through hands-on learning. In: M. Berry, \& Ch. Hodgson (Eds), Adventure Education: An Introduction (pp. 206-218). London: Routledge.

[2] Baden-Powell, R. (1908). Scouting for Boys. United Kingdom: Oxford University Press.

[3] Bobilya, A., Akey, L., \& Mitchell, D. (2011). Outcomes of a spiritually-focused outdoor education program. Journal of Experiential Education, 33(1), 301-322.

[4] Cason, D., \& Gillis, H. (1994). A meta-analysis of outdoor adventure programming with adolescents. Journal of Experiential Education, 17(1), 40-47. 
[5] Christ, M. (2012). Edukacja przygodą w pracy z dziećmi oraz studentami pedagogiki [Education as adventure in working with kids and students of pedagogy]. In: E. Palamer-Kabacińska, \& A. Leśny (Eds.), Edukacja przygodą. Outdoor i Adventure Education w Polsce: teoria, przykłady, konteksty [Educating with Adventure. Outdoor and Adventure Education in Poland: Theory, Examples, Contexts] (pp. 110-126). Warszawa: Fundacja Pracowania Nauki i Przygody.

[6] Danks, F., \& Schofield, J. (2007). Nature's Playground: Activities, Crafts, and Games to Encourage Children to Get Outdoors. Chicago: Chicago Review Press.

[7] Dewey, J. (1910). How We Think. Boston-New York-Chicago: D.C. Heath \& Co., Publishers.

[8] Gass, M.A. (1995). Adventure Family Therapy: An Innovative Approach Answering the Question of Lasting Change with Adjudicated Youth?. Monograph on Youth in the 1990s, 4, 103-117.

[9] Gerrig, R., \& Zimbardo, P. (2002). Psychology and Life. Boston-London-Toronto-SydneyTokyo-Singapore: Allyn \& Bacon.

[10] Gray, T., \& Martin, P. (2012). The Role and Place of Outdoor Education in the Australian National Curriculum. Australian Journal of Outdoor Education, 16(1), 39-50.

[11] Gustafsson, P., Szczepanski, A., \& Nelson, N. (2012). Effects of an outdoor education intervention on the mental health of schoolchildren. Journal of Adventure Education and Outdoor Learning, 12, 63-80.

[12] Hall, E.T. (1990). The Hidden Dimension. New York: Anchor Books.

[13] Heidegger, M. (1962). Being and Time (trans. J. Macquarrie, \& E. Robinson). London: S.C.M.

[14] Higgins, P., \& Loynes, C. (1996). Towards Consensus on the Nature of Outdoor Education. The Journal of Adventure Education and Outdoor Leadership, 13(4), 2-3.

[15] Hovelynck, J. (2000). Recognising and exploring action-theories: A reflection-in-action approach to facilitating experiential learning. Journal of Adventure Education and Outdoor Learning, 1, 7-20.

[16] Hunt, J. (Ed.) (1989). In Search of Adventure: A Study of Opportunities for Adventure and Challenge for Young People. Guildford: Talbot Adair Press.

[17] Kolb, D.A. (1984). Experiential learning: Experience as the source of learning and development. Englewood Cliffs, NJ: Prentice-Hall.

[18] Konner, M.J. (1972). Aspects of the developmental ethnology of a foraging people. In: N. Blurton-Jones (Ed.), Ethological Studies of Child Behaviour (pp. 285-304). Cambrige: Cambrige University Press.

[19] Leksicka, K. (1999). „Dzieci odkrywają przyrodę”: edukacja ekologiczna inaczej [“Kids discover nature": Different take on ecological education otherwise]. In: J. Gnitecki, \& J. Rutkowiak (Eds.), Pedagogika i edukacja wobec nadziei i zagrożeń współczesności. Materiały z III Ogólnopolskiego Zjazdu Pedagogicznego [Pedagogy and Education in the Face of Hopes and Threats of Modernity: Materials from the 3rd Polish National Congress of Education] (pp. 329-337). Warszawa-Poznań: Polskie Towarzystwo Pedagogiczne.

[20] Lepper, M., Sethi, S., Dialdin, D., \& Drake, M. (1997). Intrinsic and Extrinsic Motivation: A Developmental Perspective. New York: Cambridge University Press.

[21] Lewin, A. (1983). System wychowania a twórczość pedagogiczna [System of Upbringing and Pedagogical Output]. Warszawa: Państwowe Wydawnictwo Naukowe.

[22] Luckmann, C. (1996). Defining Experiential Education. The Journal of Experiential Education, 19(1), 6-7.

[23] Małkowski, A. (1911). Scouting jako system wychowania młodzieży [Scouting as a System of Youth Upbringing]. Lwów: Związek Polskich Gimnastycznych Towarzystw Sokolich.

[24] Martin, P. (2008). Outdoor education in senior schooling: Clarifying the body of knowledge. Australian Journal of Outdoor Education, 12(1), 13-23.

[25] Mendel, M. (2006). Wstęp [Introduction]. In: M. Mendel (Ed.), Pedagogika miejsca [Pedagogy of Place]. Wrocław: Wydawnictwo Naukowe Dolnośląskiej Szkoły Wyższej Edukacji TWP.

[26] Miles, J.C., \& Priest, S. (1990). Adventure Education. State College, PA: Venture Publishing.

[27] Nietzsche, F. (1911). Ecce Homo (trans. A.M. Ludovici). Portland, Maine: Smith \& Sale.

[28] Piaget, J. (1937). La construction du réel chez l'enfant. Neuchâtel: Delachaux et Niestlé.

[29] Piątek, Z. (2005). Człowiek jako podmiot zrównoważonego rozwoju: konsekwencje filozoficzno-społeczne [Human being as a subject of sustainable development: Philosophical 
and social consequences]. In: A. Papuziński (Ed.), Zrównoważony rozwój. Od utopii do praw człowieka [Sustainable Development: From Utopias to Human Rights] (pp. 21-30). Bydgoszcz: Oficyna Wydawnicza Branta.

[30] Rickinson, M., Dillon, J., Teamey, K., Morris, M., Choi, M.Y., Sanders, D., \& Benefield, P. (2004). A Review of Research on Outdoor Learning: Executive Summary. Retrieved from: http://www.peecworks.org/peec/peec_research/01795BFA-001D0211.0/NFER\%2520Exec $\% 2520$ Summary.pdf.

[31] Ringer, T.M. (2004). A Subjective Description of Adventure Therapy. In: I. Martínková, \& M. Peliš (Eds.), Movement - the art of life I (pp. 73-92). Prague: Charles University in Prague.

[32] Rubens, D. (1997). Outdoor Education, Adventure and Learning: A Fusion. Edinburgh: University of Edinburgh.

[33] Scrutton, R. (2014). Outdoor adventure education for children in Scotland: Quantifying the benefits. Journal of Adventure Education and Outdoor Learning, 15, 123-137.

[34] Seton, E.T. (1913). The Book of Woodcraft and Indian Lore. New York: Doubleday.

[35] Szczepaniec-Cięciak, E. (2004). Relacje między pedagogiką a ekologią na przykładzie nauczania i wychowania dla zrównoważonego rozwoju [Relationship between pedagogy and ecology on the example of teaching and upbringing for sustainable development]. In: S. Palka (Ed.), Pogranicza pedagogiki i nauk pomocniczych [Borderlands of Pedagogy and Auxiliary Sciences] (pp. 251-269). Kraków: Wydawnictwo Uniwersytetu Jagiellońskiego.

[36] Śniadek, B. (2007). Konstruktywistyczne podejście do nauczania o świetle i jego właściwościach [Constructivist approach towards teaching about light and its properties]. In: S. Dylak (Ed.), Przyroda. Badania. Język: Przyrodnicze rozumowanie i komunikowanie się najmłodszych [Nature. Research. Language: Natural logic and communication of the youngest] (pp. 40-46). Warszawa: Wydawnictwa CODN.

[37] Tuan, Y.-F. (1977). Space and Place: The Perspective of Experience. Minneapolis: University of Minnesota Press.

[38] Webster, R. (2015). 121 Amazing Banksy Graffiti Artworks with Locations. Retrieved from: https:// www.canvasartrocks.com/blogs/posts/70529347-121-amazing-banksy-graffitiartworks-with-locations.

[39] Wojciechowski, K. (1987). Wstęp [Introduction]. In: Y.-F. Tuan. Przestrzeń i miejsce [Space and Place] (pp. 5-6). Warszawa: Państwowy Instytut Wydawniczy.

[40] Wollman-Mazurkiewicz, L. (1998). Na tropach praktyki w klasach młodszych: edukacja ekologiczna jako przygoda [On the trail of practice in primary education of the youngest: ecological education as an adventure]. In: J. Solomon, \& S. Dylak (Eds), Dziecko w świecie przyrody i nauki [Child in the World of Nature and Science] (pp. 190-211). Toruń: Edytor.

[41] Wurdinger, S. (1995). Philosophical Issues in Adventure Education. Dubuque, IA: Kendall/ Hunt.

[42] Znaniecki, F. (1938). Socjologiczne podstawy ekologii ludzkiej [Sociological basis of human ecology]. Ruch Prawniczy, Ekonomiczny i Socjologiczny, 18(1), 89-119. 